体力科学 (2004) 53, 391 402

\title{
表面筋電図逆解析シミュレーションによる筋単位サイズと筋線維密度の推定
}

\author{
斎藤健 治 $^{1)}$ 増 田 正 $^{2)}$ 岡田守彦 ${ }^{3)}$
}

\section{MUSCULAR UNIT SIZE AND FIBER DENSITY DEDUCED FROM SIMULATION OF INVERSE ANALYSIS OF SURFACE ELECTROMYOGRAMS}

\author{
Kenji Saitou, Tadashi Masuda and Morihiko Okada
}

\begin{abstract}
The purpose of this study was to noninvasively extract information about the size and muscle fiber density of muscular units through the inverse analysis of surface electromyograms. Surface motor unit action potentials (MUAPs) were recorded with a multi-channel electrode array arranged along the circumference direction of the biceps brachii. The depth and intensity of equivalent current dipoles were estimated through the inverse analysis of surface MUAPs. The simulation of inverse analysis of surface potentials generated by the muscular unit models showed that the relationship between the depth and the intensity depends on the muscular unit size and muscle fiber density.

In the simulation, we systematically varied the model parameters including distance from the skin, radius, and fiber density and used the inverse analysis to estimate the depth and intensity of current dipoles. And, our method to estimate the radius and fiber density of muscular units using estimated depth and intensity is demonstrated. Mean values $( \pm S D)$ estimated from the surface MUAPs were $3.0 \pm 1.8 \mathrm{~mm}$ for depth and $13.8 \pm 32.0 \mathrm{nAm}$ for intensity. The estimated distance ranged from slightly less than $1 \mathrm{~mm}$ to slightly more than $2 \mathrm{~mm}$. The estimated radius ranged from 1.8 to $4.6 \mathrm{~mm}$ and fiber density from 0.7 to $5.4 \mathrm{fibers} / \mathrm{mm}^{2}$.
\end{abstract}

(Jpn. J. Phys. Fitness Sports Med. 2004, $53: 391 \sim 402$ )

key word : muscular unit, size, fiber density, inverse analysis, surface EMG

\section{I . 緒}

表面筋電困は，多くの運動単位の活動電位が重 畳して，皮膚表面で観測された干渉波形である。 したがって，同時に多くの連動単位活動を非侵襲 的に記録できる利点がある一方，筋内筋電図のよ うに，個々の運動単位 (筋単位)の活動を分離記録 し情報抽出することは難しい. 表面筋電図法のこ のような欠点を補う新たな計測方法を確立するた めに, 著者らは表面筋電図の逆解析を行ってきた 1,2).この逆解析では, 活動筋線維あるいは活動 筋単位を 1 個から 7 個の等価電流双極子(以下, 電 流双極子) で近似し, その深さと強度を最適化計
算により推定した。そして，逆解析の妥当性，す なわち推定された深さ (位置)の尤もらしさは, 動 物実験による組織化学的分析により検証した3）.

ところで, 著者らの表面筋電図逆解析は, 筋内 電極計測の代替を目標としており, 次の段階とし て，筋単位の形態 (サイズや筋線維密度)の推定が 課題の一つとなる，筋単位のサイズや筋線維密度 の推定については, ほとんどの先行研究におい て，針筋電図 ${ }^{4)}$, マクロ筋電図やスキャニング筋

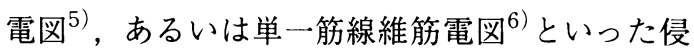
襲的な筋内電極が用いられている. 唯一, Roeleveld et al. ${ }^{7)}$ が, 筋内電極と多点表面電極に よる計測結果を比較し，非侵襲的な表面電極で筋

\footnotetext{
1) 佐賀大学理工学部都市工学科

于 840-8502 佐賀県佐賀市本庄町1

2) 東京医科歯科大学大学院疾患生命科学研究部 干101-0062 東京都千代田区神田駿河台2-3-10

3) 筑波大学先端学際領域研究センター テ305-8577 つくば市天王台1-1-1
}

Department of Civil Engineering, Saga University, 1 Honjo, Saga-shi, 840-8502

School of Biomedical Science, Tokyo Medical and Dental University, 2-3-10 Kandasurugadai, Chiyoda-ku, 101-0062 Center for Tsukuba Advanced Research Alliance, University of Tsukuba, 1-1-1 Tennodai, Tsukuba-shi, 305-8577 
単位サイズを推定する方法を提案している。この ように, ヒトの神経筋系を知る上で, 筋単位の形 態に関する情報は，発火頻度や同期現象などの機 能的知見とともに重要なファクターであるが，そ れらの情報が非侵襲的に得られることも，研究の 発展性の意味で重要なファクターとなりうる.

そこで本研究では, 表面筋電図逆解析とその数 值シミュレーションいう非侵襲的手法により，筋 単位の形態に関する情報の抽出を目的としてい る.ここでは, 計測した表面運動単位活動電位 (表 面 MUAPs)の逆解析により推定される電流双極 子の深さと強度の関係を, 筋単位のサイズと筋線 維密度に帰着した。つまり,さまざまなサイズと 筋線維密度をもつ筋単位モデルが生成する表面電 位の逆解析を行い(数值シミュレーション), この シミュレーションを通して得られた関数関係を用 いて, ヒト表面 MUAPs の活動源である筋単位 のサイズと筋線維密度を推定した。

\section{II . 方法}

\section{A . 表面 MUAPs 計測と逆解析}

被験者は，24，30，42歳の 3 名の健康な成人男 性であった。被験者に上腕二頭笳の等尺性収縮を 行わせ, 多点電極により表面 MUAPs を計測し た. 上腕二頭筋の等尺性収縮は, 肘関節角度約 130
度 (最大伸展が180度)で 3 秒間, 個々の MUAP が識別できる程度の弱さであった。多点電極は, $0.7 \mathrm{~mm}$ 角の電極接点を筋線維方向に $5 \mathrm{~mm}$ 間隔 で配置して構成した双極電極を，それに直交する 方向(筋周囲方向)に $2.5 \mathrm{~mm}$ 間隔で16個並べた電 極列であった(Fig. 1). 表面 MUAPsは，上腕二 頭筋の神経支配帯部分 ${ }^{8)}$ より遠位側と近位側にお いて十数回計測した.

表面 MUAPs は 53〜1,000 Hz の周波数帯域で 増幅し, $50 \mathrm{~Hz}$ のハムフィルタをかけた。増幅し た信号は,サンプリング周波数 $5 \mathrm{kHz}$, 精度 12 bit, 長さ $3 \mathrm{~s}$ で A/D 変換した.

表面 MUAPsはピーク時刻を基準に加算平均 し，逆解析の入力信号とした. そして, Saitou et $\mathrm{al}^{2}{ }^{2)}$ と同様の方法により, 電流双極子の深さと強 度を推定した。

\section{B . 逆解析シミュレーション}

筋単位モデルにより生成される表面電位の逆解 析により，一個の電流双極子の深さと強度を推定 する，逆解析シミュレーションを行った。

筋単位モデルは, 種々のサイズ(半径) と筋線維 密度をもち，筋横断面上で円形領域をもつものと した ${ }^{4)}$ (Fig. 2 a, b , c). Fig. 2 b に示すように，筋 単位モデルの半径 $r$ は, $1.25,2.5,5 ， 10$ よ

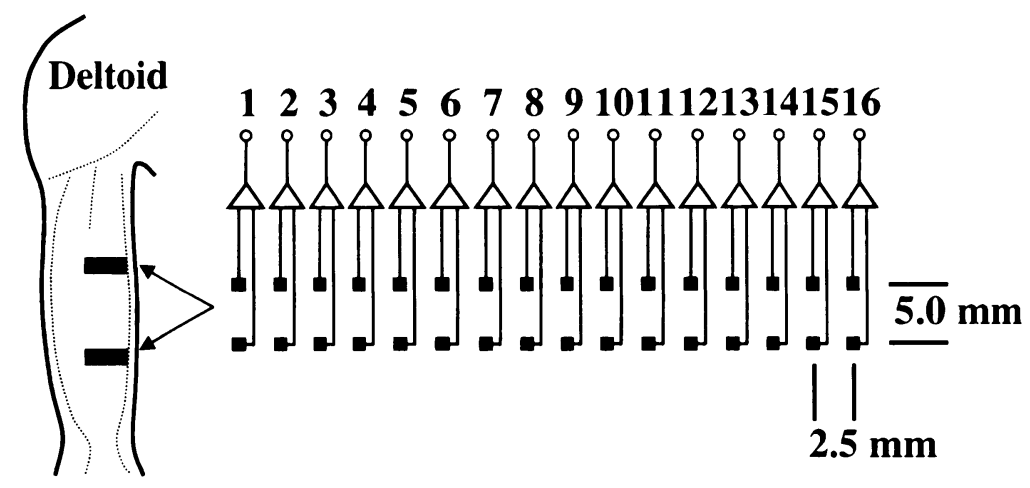

Fig. 1. Motor unit action potentials were detected with a surface electrode array placed over the biceps brachii muscle. The individual bipolar electrode consisted of the contacts placed at $5 \mathrm{~mm}$ intervals in the direction of the muscle fibers. The surface electrode array consisted of 16 pairs of bipolar electrodes arranged along the circumference direction of the muscle. The electrode array was positioned over either a proximal area or a distal area of the muscle to avoid the innervation zones of the biceps brachii. 
(a)

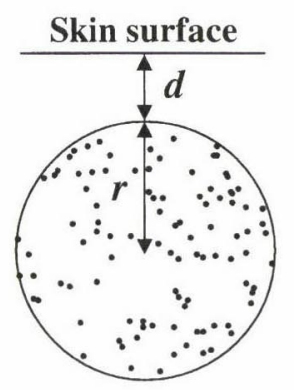

(b)

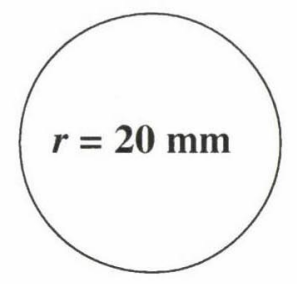

(c)
$2.5 \mathrm{~mm}$

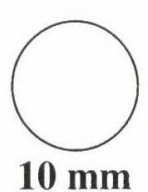

$10 \mathrm{~mm}$

\section{$1.25 \mathrm{~mm}$}

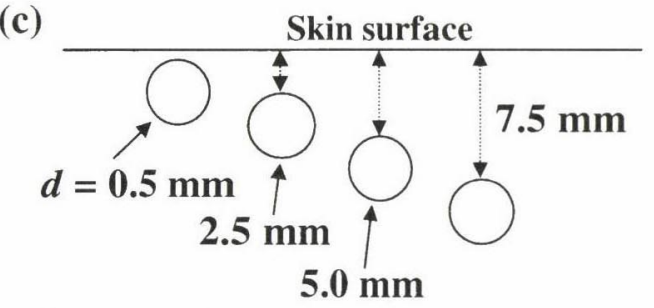

Fig. 2. Schema of the muscular unit model used for numerical simulation in this study. (a) Dots within the circle represent the muscle fibers belonging to a single motor unit. (b) Five types of muscular unit models with radii ranging from $1.25 \mathrm{~mm}$ to $20.0 \mathrm{~mm}$ were prepared for the simulation. (c) Distances to the edge of the muscular unit terri. tory d ranged from $0.5 \mathrm{~mm}$ to $7.5 \mathrm{~mm}$.

び $20 \mathrm{~mm}$ の 5 種類とした。そして，皮膚表面か

ら筋単位モデル領域までの距離 $d$ を0.5,2.5,

5 および $7.5 \mathrm{~mm}$ の 4 種類とした (Fig. $2 \mathrm{c})$. また, 5 種類の半径をもつ筋単位モデルのそれぞれに,
$0.4 ， 1.6 ， 2.5 ， 5.0 ， 10.2$ および 20.0 fibers/ $\mathrm{m} \mathrm{m}^{2}$ の 6 種類の筋線維密度 $f_{d}$ を想定した ( F i g. 3).これらは, 筋線維数にすると 2 ○,283個で あった。

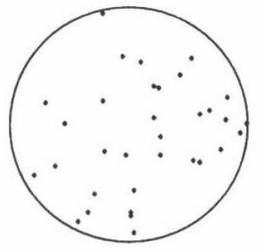

\section{4 fibers $/ \mathrm{mm}^{2}$}

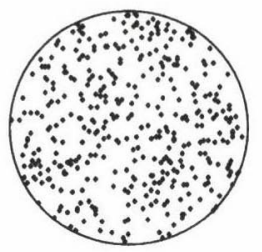

\section{0 fibers $/ \mathrm{mm}^{2}$}

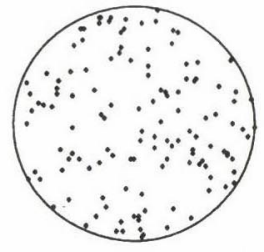

1.6 fibers $/ \mathrm{mm}^{2}$

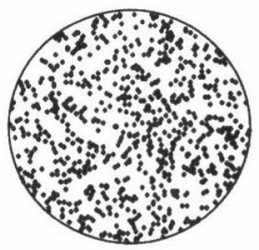

10.2 fibers $/ \mathrm{mm}^{2}$

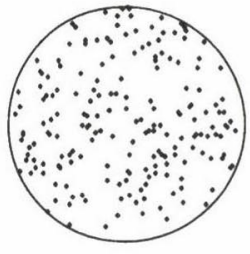

\section{5 fibers $/ \mathrm{mm}^{2}$}

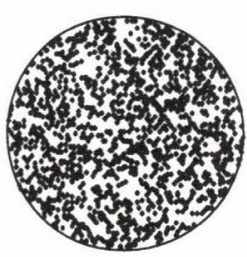

\section{0 fibers $/ \mathrm{mm}^{2}$}

Fig. 3. In the simulation, 50 muscular units containing distinct muscle fiber distribu. tions was generated at each fiber density of the model. The figures show examples of the muscular unit model using a fiber density of 0.4 to 20.0 fibers $/ \mathrm{mm}^{2}$. The positions of muscle fibers in the cross sections were generated uniformly using random numbers. 
モデルの筋線維分布は二次元平面上で一様ラン ダムとし9,10)，6種類それぞれの筋線維密度に おいて 50 種類の分布を, 一様分布に従う乱数を発 生させて実現した。したがって，計6,000通りの 組み合わせで表面電位を生成し, 逆解析により筋 単位領域の中心の深さ $D(=d+r$, Fig. 2 a $)$ と強度 を推定する，一連のシミュレーションを行った。 電位生成に際して, 電流双極子の双極子モーメン 卜(強度)は, Andreassen and Rosenfalck ${ }^{11)} の$ 值 $(0.29 \mathrm{nAm})$ と同程度の $0.3 \mathrm{n} \mathrm{Am}$ (nano ampere meter)とした.

\section{III. 結果}

\section{A. 表面 MUAPs 逆解析結果}

3 人の被験者から導出した MUAPs は計 46 個 であった。そして, 逆解析により推定された電流 双極子数は 1 個の MUAP につき $3 \sim 8$ 個で, 計 215個であった。深さ推定の最大值は $7.7 \mathrm{~mm}$ で, $6 \mathrm{~mm}$ 以下の推定值が $90 \%$ を占めた。 また, 強度 の推定值の最大は $230.9 \mathrm{nAm}$ で $10 \mathrm{nAm}$ 以下が $80 \%$ を占めた. 深さ推定值と強度推定值の平均は,
それぞれ $3.0 \pm 1.8 \mathrm{~mm}, 13.8 \pm 32.0 \mathrm{nAm}$ であっ た。

Fig. 4 亿，表面 MUAP 波形 (Measured MUAP) と, 逆解析により推定した電流双極子が生成する 表面電位波形 (Calculated MUAP)の一例を示す. 上図が MUAP の三次元表面図, 下図がMUAP の等電位線図である.ともに, 筋周囲(チャンネル) 方向-時間方向のプロットである。この例では, 逆解析によるあてはまりの良さ goodness of fit は 91.0\%であった。そして，推定された電流双極子 数は 5 個で, 深さは $6.28,6.1 ， 3.37,3.41$ お び $3.58 \mathrm{~mm}$ ，強度は41.06，38.76，14.78，15.25 および $0.72 \mathrm{nAm}$ であった。

Fig. 5 a に，導出したMUAPs の逆解析による 電流双極子の推定值を, 深さ一強度平面にプロッ 卜した図を示す。両者の間には $\mathrm{R}^{2}=0.69$ の指数 関数関係がみられた。 そして, 浅く, 強度の大き い電流双極子は推定されなかった。

\section{B．逆解析シミュレーション結果}

筋単位モデルの表面電位から推定した電流双極

\section{Measured MUAP}
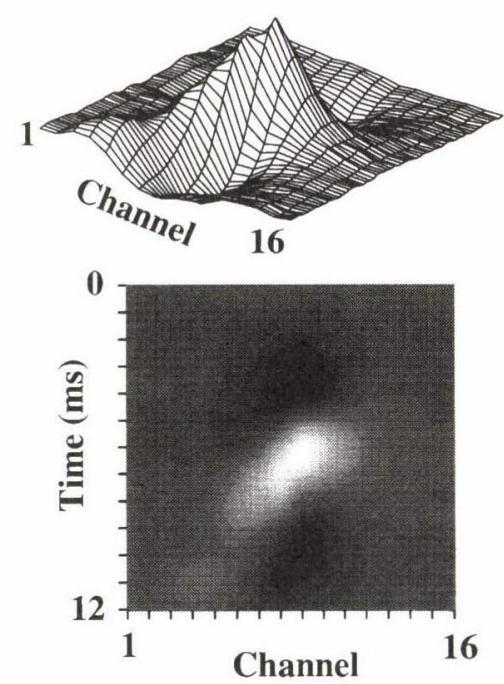

\section{Calculated MUAP}
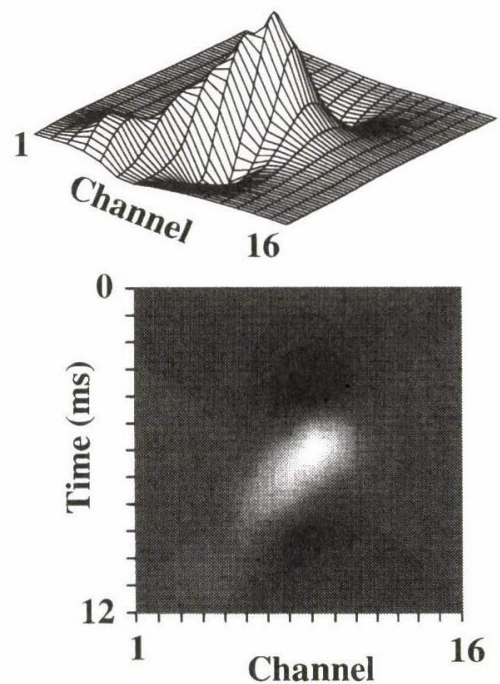

Fig. 4. Surface plots (upper row) and contour plots (lower row) of measured (left) and calculated (right) motor unit action potential (MUAP) waveforms. MUAP waveforms were calculated with five current dipoles. The depths of the current dipoles were 6.28 , $6.10,3.37,3.41$, and $3.58 \mathrm{~mm}$ and the intensities of the current dipoles were 41.06 , $38.76,14.78,15.25$, and $0.72 \mathrm{nAm}$. The goodness of fit was $91.0 \%$ in this analysis. 


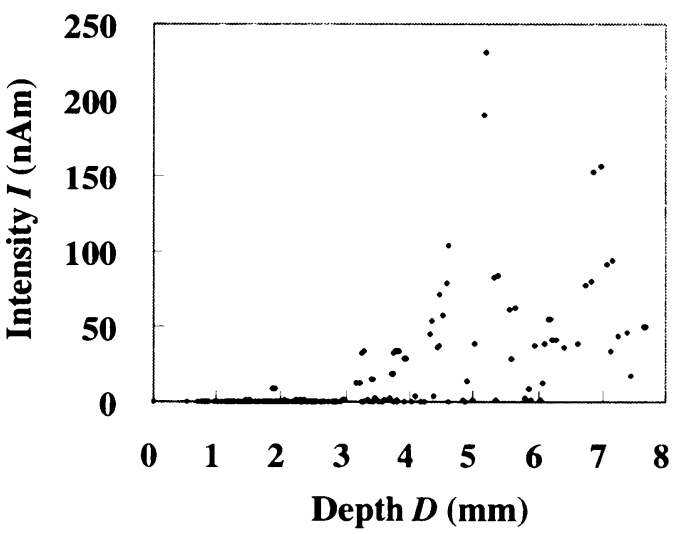

(a)

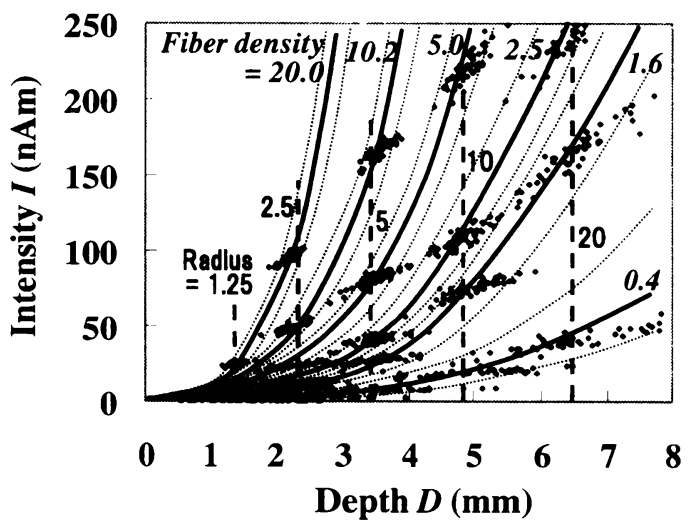

(b)

Fig. 5. (a) Relationships between depth and intensity estimated through the inverse analysis of surface motor unit action potentials. No muscular unit was found in the shallower and stronger areas. (b) Relationships between depth and intensity estimated by the numerical simulation of inverse analysis. The depth-intensity plots resulted from the simulation using the muscular unit models with a $0.5 \mathrm{~mm}$ distance to the edge. The estimated values from the muscular unit models with identical fiber density were expressed by a third-power function.

子の推定值を, 深さ一強度平面にプロットした図 を Fig. 5 b に示す。ここでは，皮膚表面から筋単 位領域までの距離 $d$ が，0.5 mm である筋単位モ デルの結果について示している。 そして，1,500 通りの組み合わせから推定された結果のうち, 深 さ $8 \mathrm{~mm}$ まで, 強度 $250 \mathrm{nAm}$ までのシミュレー ション結果を示している.

逆解析シミュレーションの結果, 同一の深さ (半 径) と筋線維密度をもつ50種類の筋単位モデルの 表面電位から推定された電流双極子は, 深さ - 強 度平面上で棈円形状にばらつきをもつ集団を形成
した Fig. 5b)。 そして, 筋単位モデルの半径が 大きく(深く)なるほど, 深さと強度の推定值とも に大きくなった，同一半径をもつ筋単位モデルの 表面電位から推定された電流双極子の深さは, Fig. 5 b の破線およびゴシック体の数值で示され ているように，深さ一強度平面上で縦の系列を形 成した。いずれも領域の中心 $(d+r)$ より浅く推定 された。一方，同一筋線維密度を持つ筋単位モデ ルの表面電位から推定された電流双極子の深さ $D$ の平均值と強度 $I$ の平均値の関係は, 深さ一強 度平面上において累乗関数,

Table 1. Coefficients $\alpha$ of third-to sixth-power functions expressing the series of inverse-analysis solutions with identical fiber density.

\begin{tabular}{c|c|l|l|c}
\hline \multirow{2}{*}{$\begin{array}{c}\text { Fiber density } \\
\left(\text { fibers } / \mathrm{mm}^{2}\right)\end{array}$} & $0.5 \mathrm{~mm}$ & $2.5 \mathrm{~mm}$ & $5 \mathrm{~mm}$ & $7.5 \mathrm{~mm}$ \\
\cline { 2 - 5 } & Order $=3$ & Order $=4$ & Order $=5$ & Order $=6$ \\
\hline 0.4 & 0.161 & 0.00669 & 0.000174 & $4.010 \mathrm{E}-06$ \\
1.6 & 0.608 & 0.0255 & 0.000666 & $1.539 \mathrm{E}-05$ \\
2.5 & 0.950 & 0.0394 & 0.00102 & $2.336 \mathrm{E}-05$ \\
5.0 & 1.867 & 0.0779 & 0.00202 & $4.636 \mathrm{E}-05$ \\
10.2 & 3.753 & 0.157 & 0.00410 & $9.441 \mathrm{E}-05$ \\
20.0 & 7.448 & & & \\
\hline
\end{tabular}




$$
I=\alpha D^{p}
$$

により近似される系列を形成した。距離 $d=0.5$ $\mathrm{mm}$ のモデルでは $p=3, d=2.5 \mathrm{~mm}$ では $p=4, d$ $=5 \mathrm{~mm}$ では $p=5, d=7.5 \mathrm{~mm}$ では $p=6$ となっ た. Fig. $5 \mathrm{~b}$ に $d=0.5 \mathrm{~mm}$ で同一の筋線維密度 をもつモデルに対する, $p=3$ の三次関数近似曲 線 (実線) と $95 \%$ 信頼限界 (破線)を示す (明朝イ夕 リック体の数值)。また，それぞれの筋線維密度 に対応する係数 $\alpha$ の值を Table 1 に示す.

\section{C. 筋単位半径と筋線維密度の推定}

3 人の被験者の上腕二頭筋 MUAPs の逆解析 により推定した，電流双極子の深さと強度を用い て，筋単位のサイズと筋線維密度を以下の手順で 求めた。

シミュレーション結果から, 筋単位モデルの半 径 $r$ と推定された深さ $D$ の関係は,

$$
r=\rho D^{2}-\eta D
$$

という二次多項式で近似できた $\left(\mathrm{R}^{2}=0.994\right.$ 1.000). したがって, 逆解析による深さの推定值 $D$ から，筋単位の半径を(2) 式により推定するこ
とができる．Fig. 6 a, b , c d に，それぞれの $d に$ 対する，二次多項式による近似結果を示す.

一方，(1)式で表される同一筋線維密度系列の 係数 $\alpha$ と筋線維密度 $f_{d}$ の関係は, Fig. 7 a, b, c, d に示すように,

$$
f_{d}=\lambda \alpha
$$

という一次関数で表された $\left(\mathrm{R}^{2}=0.999 \sim 1.000\right)$. $\alpha$ は深さと強度の推定值で表される係数,

$$
\alpha=\frac{I}{D^{p}}
$$

であるため, 逆解析の推定值から係数 $\alpha$ が決定さ れ,さらに(3)式により筋線維密度 $f_{d}$ が計算され る.

以上の関係式を用いて, 逆解析により推定され た深さ $D$ と強度 $I$ から求めた, 笳単位の半径と 筋線維密度の分布を, $d=0.5$ および $2.5 \mathrm{~mm}$ の 場合について Fig. 8 に示す. $d=0.5 \mathrm{~mm}$ の場合 では，推定された半径の平均は $5.39 \pm 6.46 \mathrm{~mm}$, 筋線維密度の平均は $0.40 \pm 0.72 \mathrm{fibers} / \mathrm{mm}^{2}$ であ った. $d=2.5 \mathrm{~mm}$ では, 半径の平均は $1.35 \pm 2.35$ $\mathrm{mm}$, 筋線維密度の平均は $9.34 \pm 16.99$ fibers/
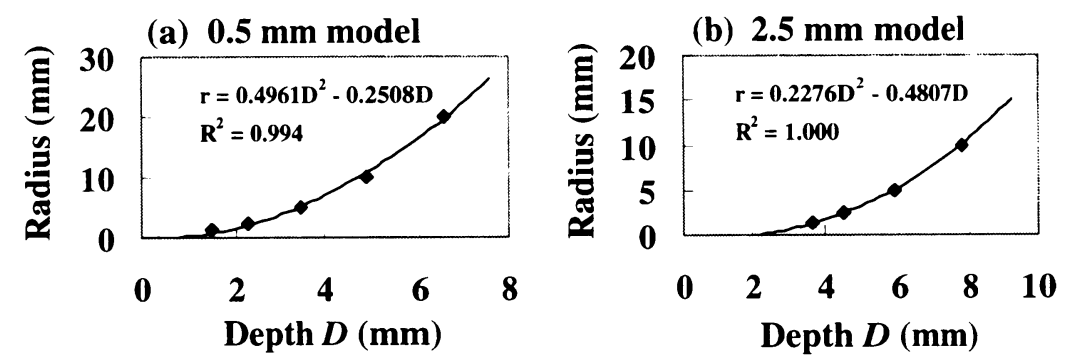

(c) $5 \mathrm{~mm}$ model

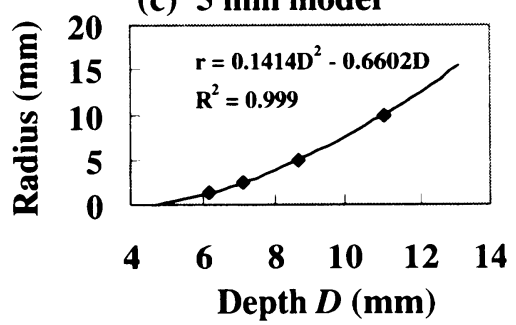

(d) $7.5 \mathrm{~mm}$ model

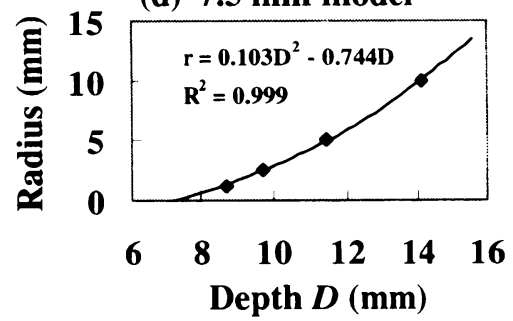

Fig. 6. Relationships between the depths of current dipoles estimated in the simulation and the radii of the muscular unit models. The radii of muscular units are expressed by a second-order polynomial equation of estimated depth. Figures (a) through (d) show the results of the model with distances to the muscular unit territory of $0.5 \mathrm{~mm}$ (a), $2.5 \mathrm{~mm}$ (b), $5 \mathrm{~mm}$ (c), and $7.5 \mathrm{~mm}(\mathrm{~d})$. 
(a) $0.5 \mathrm{~mm}$ model

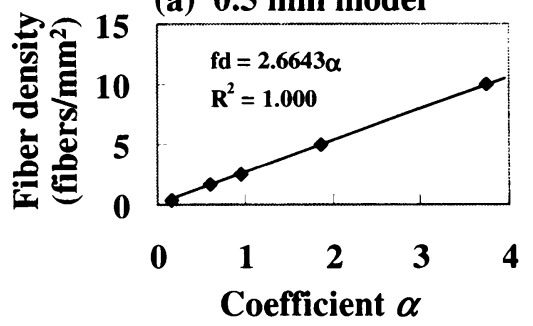

(c) $5 \mathrm{~mm}$ model

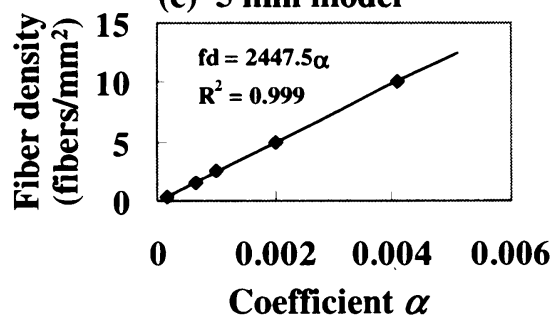

(b) $2.5 \mathrm{~mm}$ model

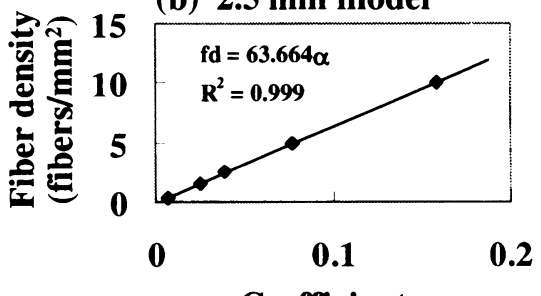

Coefficient $\alpha$

(d) $7.5 \mathrm{~mm}$ model

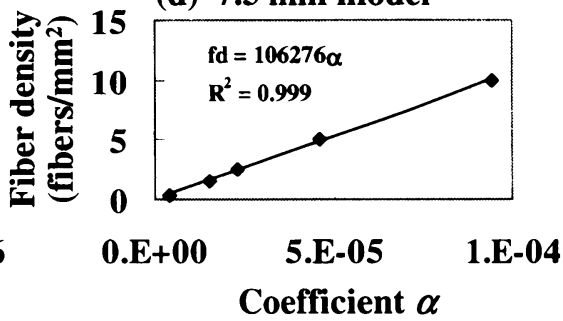

Fig. 7. Relationships between the coefficients $\alpha$ calculated from the depth and the intensity estimated through the inverse analysis and the fiber densities of muscular unit models. The fiber densities of muscular units are expressed by a first-order equation of coefficients $\alpha$. Figures (a) through (d) show the results of the model with dis. tances to the muscular unit territory of $0.5 \mathrm{~mm}(\mathrm{a}), 2.5 \mathrm{~mm}(\mathrm{~b}), 5 \mathrm{~mm}(\mathrm{c})$, and $7.5 \mathrm{~mm}$ (d).

(a) $0.5 \mathrm{~mm}$ model

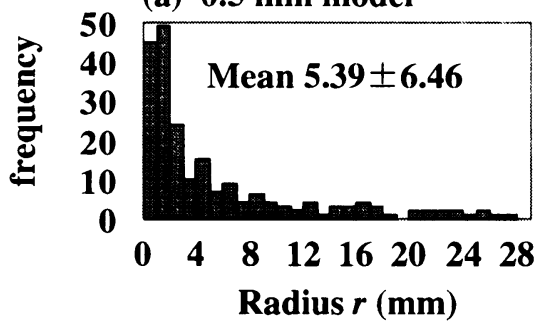

(c) $2.5 \mathrm{~mm}$ model

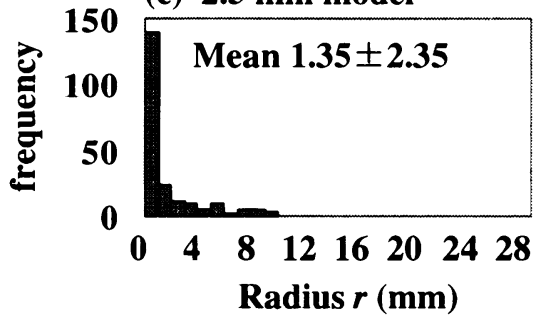

(b) $0.5 \mathrm{~mm}$ model

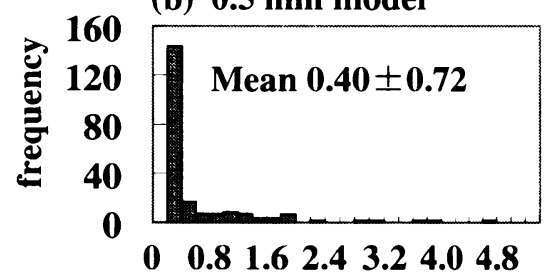

Fiber density $f_{d}\left(\right.$ fibers $\left./ \mathrm{mm}^{2}\right)$

(d) $2.5 \mathrm{~mm}$ model

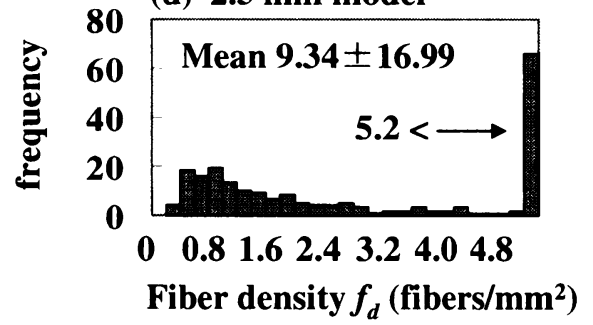

Fig. 8. Histograms showing the radius and fiber density of muscular units estimated using equations (1) through (4). Figures (a) and (b) show the distribution of the radius and fiber density calculated by the function of the depth and intensity introduced from the model in which the distance to the muscular unit territory was $0.5 \mathrm{~mm}$. Figures (c) and $(d)$ show the distribution of the radius and fiber density calculated by the function of the depth and intensity introduced from the model in which the distance to the muscular unit territory was $2.5 \mathrm{~mm}$. 
(a)

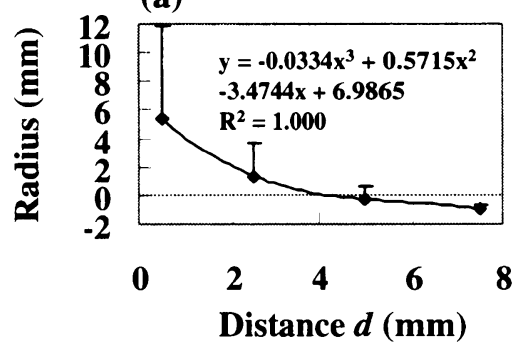

(b)

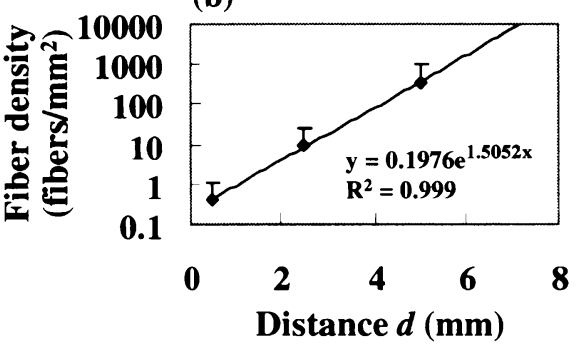

Fig. 9. The radius and fiber density calculated by equations (1) through (4) in four models with different distances to the muscular unit territory. The relationship between distance $d$ and the radius was represented by a third-order polynomial equation. The relationship between distance $d$ and muscle fiber density was represented by an exponential function. From these relationships, the distance $d$ of muscular units measured with the surface electrode array ranged from slightly less than $1 \mathrm{~mm}$ to slightly more than $2 \mathrm{~mm}$.

$\mathrm{mm}^{2}$ であった. $d=5 \mathrm{~mm}(-0.27 \pm 0.88 \mathrm{~mm}$, $\left.358.93 \pm 653.15 \mathrm{fiber} / \mathrm{mm}^{2}\right)$ および $7.5 \mathrm{~mm}(-1.00$ $\left.\pm 0.33 \mathrm{~mm}, \quad 15,585.61 \pm 28,361.26 \mathrm{fiber} / \mathrm{mm}^{2}\right)$ で は現実的な值にならなかった Fig. 9).

\section{N. 考}

察

本研究では, 逆解析により推定された電流双極 子の哚さと強度の関係に着目し，その関係に潜在 する筋単位のサイズ (半径) と筋線維密度に関する 情報を, 数值シミュレーションを通して探ること が目的であった。筋横断面上に扔ける筋単位領域 を円形と仮定した上で4), 様々な筋単位半径およ び筋線維密度をもつ, 計6,000個のモデルを構築 した。そして，これら筋単位モデルにより生成さ れた表面電位の逆解析により，単一電流双極子の 深さと強度を推定し, それら推定值と, 筋単位の サイズおよび筋線維密度の関係を明らかにした。 さらに,この関係を用いて，ヒト上腕二頭筋の筋 単位半径と筋線維密度を推定した。

\section{A . 皮膚表面から筋単位領域までの距離 $d$ に} ついて

皮虐からの距離 $d$ が $0.5,2.5,5$ および 7.5 $\mathrm{mm}$ の, それぞれの筋単位モデルが生成する表面 電位の逆解析により推定された, 電流双極子の深 さと強度の間には Table 1 に示したように，3， 4,5 および 6 次の累乗関数関係が認められた。
つまり，逆解析シミュレーションにおいて推定さ れた，深さ一強度平面上のプロットが， $d$ が大き くなるにつれて右(深い方)ヘシフトし, 計測結果 Fig. 5 a と大きくはずれる結果となった。特に, $d$ $=5$ および $7.5 \mathrm{~mm}$ のモデルをもとにする関数関 係から推定された半径と筋線維密度は, 現実的な 值にならなかった (Fig. 9).

それに対し， $d=0.5 \mathrm{~mm}$ および $2.5 \mathrm{~mm}$ のモデ ルは, 深さ一強度平面のプロットの比較から $(d=$ $2.5 \mathrm{~mm}$ は示していないが, Fig. $5 \mathrm{a}, \mathrm{b})$, 計測結 果に近いといえる。また, それぞれのモデルから 導かれる関数関係から求めた半径と筋線維密度 は, $d=0.5 \sim 2.5 \mathrm{~mm}$ において, それぞれ平均值 で $1.35 \sim 5.39 \mathrm{~mm}, 0.40 \sim 9.34$ fiber $/ \mathrm{mm}^{2}$ であり, 先行研究の報告 ${ }^{4,6)}$ を参考にすると, この間に妥 当な $d$ があると考えられる．また， $d=0.5 \mathrm{~mm}$ という值は, 通常の皮下脂肪厚よりかなり小さい 值であるが, 本研究では $0.7 \mathrm{~mm}$ 角の電極接点を 皮膚に押し当てて表面 MUAPs を計測したこと から, 結果的に距離 $d$ が小さくなり $d=0.5$ に近 くなったと考えられる.

以上の点から, 本研究において計測された表面 MUAPs の活動源である筋単位領域までの距離 $d$ は, $1 \mathrm{~mm}$ 弱〜 $2 \mathrm{~mm}$ 強程度の範囲と考えられる。 ただし, $0.7 \mathrm{~mm}$ 角の電極接点を用いたのは, 計 算モデルとの整合性の問題から，より点状で電位 を計測する必要があったためであり，インピーダ 
ンスや接触による痛み等の問題が解決されるなら ばより細い電極が望ましい，そして，皮虚を変形 させることなく電位計測ができれば， $d$ はやや大 きめの值になると考えられる.

\section{B. 筋単位半径 $r$ と筋線維密度 $t_{d}$ について}

Buchthal et al. ${ }^{4)}$ は針電極を用いた計測により, 上腕二頭筋の筋単位は直径 $5 \sim 20 \mathrm{~mm}$ の円形領 域であると報告している. 本研究の逆解析シミュ レーションを通して推定された筋単位の半径は, $d=0.5 \mathrm{~mm}$ モデルにおいて $5.39 \pm 6.46 \mathrm{~mm}, d=$ $2.5 \mathrm{~mm}$ モデルにおいて $1.35 \pm 2.35 \mathrm{~mm}$ であっ た. Buchthal et al. ${ }^{4)}$ の報告と比較すると, $d=2.5$ $\mathrm{mm}$ モデルにおいてやや值が小さくなる.しかし， 前述のようにFig. 9 a に示される関係を用いて $d$ を $1 \mathrm{~mm}$ 弱 (0.8) $2 \mathrm{~mm}$ 強 (2.2) 程度とすると, 半径は $1.8 \sim 4.6 \mathrm{~mm}$ となり, ばらつきを含めて Buchthal et al. ${ }^{4)}$ の報告に一致すると考えられる.

Stålberg and Thiele ${ }^{6)}$ は上腕二頭筋の単一筋線 維筋電図を計測し, 筋単位の筋線維密度は平均 1.33であったと報告している。この值は, 本研究 と同等の単位に変換すると $6.8 \mathrm{fibers} / \mathrm{mm}^{2}$ とな る. 本研究の逆解析シミュレーションを通して推 定された筋単位の筋線維密度は, $d=0.5 \mathrm{~mm}$ モ デルにおいて $0.40 \pm 0.72$ fibers $/ \mathrm{mm}^{2}, d=2.5$ $\mathrm{mm}$ モデルにおいて $9.34 \pm 16.99$ fibers $/ \mathrm{mm}^{2}$ で あった. $d=0.5 \mathrm{~mm}$ モデルにおいて小さく,$d=$ $2.5 \mathrm{~mm}$ モデルにおいてはかなり大きな筋線維密 度も推定された。 そこで, 前述と同様に $d$ を 0.8 $\sim 2.2 \mathrm{~mm}$ と考えると, 筋線維密度は 0.7〜 5.4 fibers $/ \mathrm{mm}^{2}$ となる。この範囲は, Stålberg and Thiele ${ }^{6)}$ の報告よりかなり小さい值を含んでお り，その点で彼らの報告と一致しない.

しかし, Stålberg and Thiele ${ }^{6)}$ の方法では, 原 理的に1.0(3.5 fibers $\left./ \mathrm{mm}^{2}\right)$ より小さい筋線維密 度は検出できない。したがって，彼らの報告をも とに, 0.7 fibers $/ \mathrm{mm}^{2}$ という小さい筋線維密度の 筋単位は存在しないと結論することはできない. ただし，このような小さい筋線維密度は，単一筋 単位の中で孤立した少数個の筋線維集団を表して いる可能性がある，表面筋電図では，皮虚に近い
筋線維活動の表面電位への影響が大きくなる，そ のため，筋単位中の少数個の筋線維が孤立して皮 虑表面近くにあった場合，浅く弱い電流源として 推定され, 結果的に小さい筋線維密度として算出 される可能性は否定できない.同様の理由により, 小さい半径の筋単位として推定される可能性もあ る。

一方，ヒト表面 MUAPs の推定結果において， 浅く強度の大きい電流双極子が推定されなかった (Fig. $5 \mathrm{a}$ ).これは，シミュレーション結果では 小半径かつ高密度な筋単位に相当することから， 本研究で計測された上腕二頭筋の浅い領域に, 例 えば，半径 $1.25 \mathrm{~mm}$ や $2.5 \mathrm{~mm}$ で筋線維密度が 20, $10 \mathrm{fiber} / \mathrm{mm}^{2}$ といったような, 小半径で筋線 維密度の大きい筋単位は存在しなかったと推測さ れる。

\section{C. 筋線維数の点からの考察}

Christensen ${ }^{12)}$ は, ヒト胎児筋の組織化学的研 究により, 上腕二頭筋の筋単位内の筋線維数の平 均は163個であったと報告している. Feinstein et $\mathrm{al}^{13)}$ は, 同様にヒト筋の組織化学的研究により, 上腕筋と前脛骨筋は400 700個で, 腓腹筋は2,000 個であったと報告している。Christensen ${ }^{12)}$ の報 告が胎児の上腕二頭筋であることと，上腕二頭筋 と同程度の筋サイズといえる上腕筋と前頸骨筋に 関する Feinstein et al. ${ }^{13)}$ の報告から推測すると， 成人の上腕二頭筋の単一筋単位内の筋線維数は, 概略, 三桁の範囲 $(100 \sim 1,000$ で平均 500 程度) と 考えられる。これらの筋線維数は, 本シミュレー ションにおけるモデルでは, 半径において 1.25 $\sim 20 \mathrm{~mm}$ ，筋線維密度において 0.4〜10.2 fiber/ $\mathrm{mm}^{2}$ に相当する。ただ, 半径 $10 \mathrm{~mm}$ で筋線維 密度が $10 \mathrm{fiber} / \mathrm{mm}^{2}$ 以上, 半径 $20 \mathrm{~mm}$ で筋線維 密度が $1.6 \mathrm{fiber} / \mathrm{mm}^{2}$ 以上のような大サイズ, 高 密度な筋単位が存在する可能性は含まれない。こ れらは, 前述した半径および筋線維密度の範囲, $1.8 \sim 4.6 \mathrm{~mm}$ と0.7〜 5.4 fibers $/ \mathrm{mm}^{2}$ よりも幅広 く荒い見積もりとなるが，これらを支持する值と いう点で意味がある。

ただし，小サイズ，低密度な筋単位の場合にお 
いては, 二桁以下の筋線維数の可能性を許容する こととなり, Feinstein et al. ${ }^{13)}$ が報告した值から 外れてしまう。このようなサイズと密度の推定值 は, 前節 (B. 筋単位半径 $r$ と筋線維密度 $f_{d}$ につ いて)でも述べたように，一個の筋単位の形態を 表しているのではなく，筋単位の部分あるいは孤 立した筋線維集団を反映していると考えられる。

\section{D. 本研究における問題点と今後の課題}

ヒト筋単位の形態に関する先行研究では, 筋内 電極を用いたもの ${ }^{4.5,9.14)}$ が多く，それに関連し た筋内電極法のシミュレーションが散見される 10.15,16). 侵襲的な手法は, ヒトを被験者とする 場合, 資格, 被験者の同意, 限局された計測範囲, 静的・弱収縮条件などの制約下におかれる。した がって，非侵襲的な計測分析方法の開発が望まれ るが, Roeleveld et al. ${ }^{7)}$ が非侵襲的な方法を提案 しているにすぎない，本研究は，非侵襲的に筋単 位の形態に関する情報を得ることを目的としてお り，以下のような点における改善を行うことで, さらに神経筋生理学分野の研究に貢献できると考 えられる。

表面筋電図はほとんどの発揮張力下で干渉波形 となるため，多数の情報を含んでいるものの分析 は容易ではない。計測手法や信号処理手法の工夫 により，干渉波形から MUAP 波形の分離抽出が 可能になれば17)，大きな張力発揮下において活 動参加する筋単位の機能形態に関する情報抽出が 可能となる.

また，筋周囲方向の電極列の長さを大きくする ことにより，より深い位置にある筋単位の活動を 記録することができる. Roeleveld et al. ${ }^{7)}$ は，筋 周囲方向 $108 \mathrm{~mm}$ の電極列で計測可能な深さを $22 \mathrm{~mm}$ と報告しており，このことから類推する と, 本研究の電極列ではその限界が $7.6 \mathrm{~mm}$ 程度 と推定される。これは, 本研究の逆解析結果とほ ぼ一致する。

より深い筋単位を対象とする場合，境界の影響 を無視できなくなる ${ }^{18)}$ 。逆解析における電場計 算方法としての影像法の妥当性は, 数值解析お よび組織化学的解析により検証されているもの
$の^{3,18)}$, 境界, 皮下組織などを考慮したモデル の緻密化による拡張が必要になるだろう。

また, 本逆解析シミュレーションでは, 円形領 域の筋単位を単一の電流双極子により推定した。 したがって筋単位サイズが小さい場合には十分で あるが(半径 $1.25 \mathrm{~mm}$ の場合の goodness of fit は $99.4 \pm 0.4 \%)$ ，サイズが大きい場合は当てはまり の度合いが低下した(半径 $20 \mathrm{~mm}$ の場合は $82.6 \pm$ $1.5 \%)$. 複数個の電流双極子による推定を行えば, サイズの大きい筋単位モデルを用いた場合の逆解 析のあてはまり度が向上すると同時に, 筋線維分 布と電流双極子の関係が明確になったかもしれな い. 例えば, 小半径, 低筋線維密度を表現する電 流双極子は, 単一筋単位内のやや孤立した筋線維 集団を表している可能性がある。このような場合 には，一様分布より正規分布による筋線維分布表 現の方が適しているかもしれない ${ }^{19)}$ 。これらの 点については今後の課題としたい.

\section{V.まと め}

本研究では, 逆解析により推定された電流双極 子の深さと強度の関係に着目し, その関係に潜在 する筋単位のサイズ (半径) と筋線維密度に関する 情報を, 数值シミュレーションを通して抽出する ことが目的であった。筋周囲方向の多点電極列を 用いて表面 MUAPs を記録し，逆解析により電 流双極子の深さと強度を推定した。一方, シミュ レーションとして，5種類の筋単位半径および 6 種類の筋線維密度をもつ計 6,000 個のモデルを構 築し，これら筋単位モデルにより生成された表面 電位の逆解析により, 単一電流双極子の深さと強 度の推定を行った。シミュレーションにおいて推 定された，電流双極子の深さ一強度の関係に対す るモデルの半径と筋線維密度の関係を計測值の逆 解析結果に適用し, ヒト上腕二頭筋の筋単位の半 径と筋線維密度を推定した。

計測值から推定された電流双極子の深さと強度 は, $3.0 \pm 1.8 \mathrm{~mm}, 13.8 \pm 32.0 \mathrm{nAm}$ であった。 計測結果とシミュレーションの比較および関数関 係から, 皮虐表面から筋単位領域端までの距離 $d$ は $1 \mathrm{~mm}$ 弱 $2 \mathrm{~mm}$ 強程度の範囲で, 半径 $r$ は 1.8 
$\sim 4.6 \mathrm{~mm}$, 筋線維密度 $f_{d}$ は $0.7 \sim 5.4$ fibers/ $\mathrm{mm}^{2}$ 程度と推定された。これら推定值の精度を 向上させるためには,モデルの拡張が必要となる。 さらにこれら手法の適用可能性を向上させるた めには，干渉波形から MUAPs を分離する信号 処理法を併用する必要がある。

（受理日 平成16年 6 月10日）

\section{参考文献}

1）斎藤健治, 岡田守彦, 增田 正, 佐渡山覀兵, 表 面筋電図逆解析による活動電流源の推定, バイオ メカニズム，(1996)，13，89-98.

2) Saitou, K., Masuda, T. and Okada, M. Depth and in. tensity of equivalent current dipoles estimated through an inverse analysis of surface electromyog. rams using the image method, Med. Biol. Eng. Comput.. (1999), 37, 720-726.

3）斎藤健治, 増田 正, 岡田守彦, 表面筋電四逆解 析により推定した活動筋単位の位置の妥当性，（投 稿中).

Saitou, K., Masuda, T. and Okada, M. Validity of location of muscular units estimated through in. verse analysis of surface electromyograms. Jpn. J. Phys. Fitness Sports Med., (submitted).

4) Buchthal, F., Erminio, F. and Rosenfalck, P. Motor unit territory in different human muscles, Acta Phy. siol. Scand., (1959), 45, 72-87.

5) Hilton-Brown, P. and Stålberg, E. Motor unit size in muscular dystrophy, a macro EMG and scanning EMG study, J. Neurol. Neurosurg. Psychiatry, (1983), 46, 996-1005.

6) Stálberg, E. and Thiele, B. Motor unit fibre density in the extensor digitorum communis muscles- Single fibre electromyographic study in normal subjects at different ages, J. Neurol. Neurosurg. Psychiatry, (1975), 38, 874-880.

7) Roeleveld, K., Stegeman, D. F., Falck, B. and Stálberg, E. V. Motor unit size estimation : confrontation of surface EMG with macro EMG., Elec- troenceph. Clin. Neurophysiol.,(1997), 105, 181-188.

8) Saitou, K., Masuda, T., Michikami, D., Kojima, R. and Okada, M. Innervation zones of the upper and lower limb muscles estimated by using multichannel surface EMG, J. Human Ergol.,(2000), 29, 35-52.

9) Gath, I. and Stálberg, E. On the measurement of fibre density in human muscles, Electroenceph. Clin. Neurophysiol.,(1982), 54, 699-706.

10) Shenhav, R. and Gath, I. Simulation of spatial distribution of muscle fibres in human muscles, Comput. Meth. Progr. Biomed.,(1986), 23, 3-9.

11) Andreassen, S. and Rosenfalck, A. Relationship of intracellular and extracellular action potentials of skeletal muscle fibres, CRC Crit. Rev. Bioeng., (1981), 6, 267-306.

12) Christensen, E. Topography of terminal motor in nervation in striated muscles from stillborn infants, Am. J. Phys. Med., (1959), 38, 17-30.

13) Feinstein, B., Lindegard, B., Nyman, E. and Wohlfart, G. Morphologic studies of motor units in normal human muscles, Acta Anat., (1955), 23, 127-142.

14) Gootzen, T. H. J. M., Vingerhoets, D. J. M. and Stegeman, D. F. A study of motor unit structure by means of scanning EMG., Muscle Nerve, (1992), 15. 349-357.

15) Hilton-Brown, P., Nandedkar, S. D. and Stálberg, E. V. Simulation of fibre density in single-fibre electromyography and its relationship to macro-EMG, Med. Biol. Eng. Comput., (1985), 23, 541-546.

16) Miller-Larsson, A. A model of spatial distribution of muscle fibres of a motor unit in normal human limb muscles, Electromyogr. Clin. Neurophysiol., (1980), 20, 281-298.

17）八名和夫, 小原啓義, 斉藤陽一, 拡張されたショッ 卜雑音における逆問題とその応用, 電子通信学会 論文誌，(1978），J61-A10，972-979.

18）斎藤健治, 増田 正, 岡田守彦, 表面筋電位順 · 逆解析における影像法の妥当性一境界の影響の 観点から一. バイオメカニズム学会誌, (1997), 21, 92-97.

19) Gath, I. and Shenhav, R. Probabilistic model of the spatial distribution of muscle fibres in human muscles, Biol. Cybern., (1985), 53, 73-78. 